\title{
DUKUNGAN SUAMI TERHADAP PEMILIHAN KONTRASEPSI IUD DI LINGKUNGAN VIII KELURAHAN BANDAR SELAMAT KECAMATAN MEDAN TEMBUNG TAHUN 2020
}

\author{
${ }_{1}$ Maulina Maawaddah, SST,M.Kes \\ STIKes Sehat Medan, Indonesia
}

\begin{abstract}
ABSTRAK
Keluarga Berencana (KB) merupakan gerakan untuk membentuk keluarga yang sehat serta sejahtera dengan dengan pembatasan menggunakan alat-alat kontrasepsi . Penelitian ini bertujuan untuk mengidentifikasi dukungan suami terhadap pemilihan kontrasepsi IUD di Lingkungan VIII Kelurahan Bandar Selamat Kecamatan Medan Tembung Tahun 2020. Desain Penelitian ini bersifat deskriftit Analitik, melalui Pendekatan Cross Sectional. Metode Pengambilan Sampel penelitian ini melalui teknik accidental (kebetulan bertemu dengan sampel). Instrumen Penelitian menggunakan kuesioner, dari hasil penelitian berdasarkan tabel yang ada dapat di lihat bahwa yang tidak mendapatkan dukungan sebanyak 19 responden (56\%) yang menggunakan ada 10 responden (29\%) dan yang tidak menggunakan ada 24 responden $(71 \%)$ sedangkan yang mendapatkan dukungan sebanyak 15 responden. Maka dapat disimpulkan bahwa ada hubungan antara yang mendukung penggunaan kontrasepsi dan yang tidak mendukung lebih banyak dari pada yang mendukung dan yang tidak mendukung lebih banyak dari pada yang tidak menggunakan sehingga saling berhubungan antara yang satu dengan yang lain.
\end{abstract}

Kata Kunci : Dukungan Suami, Kontrasepsi IUD

\begin{abstract}
Family Planning $(K B)$ is a government program designed to balance needs and population. Aim to: Identify the husband's support for IUD contraceptive selection in the VIII neighborhood of Bandar Selamat Village, Medan Tembung District in 2020. The design of this study is: Analytical Discipline. Approach: Cross Sectional. Sampling Method: using Accidental Sampling. Research Instruments: Using a questionnaire, from the results of the study based on the existing table it can be seen that 19 respondents (56\%) did not receive support using 10 respondents (29\%) and 24 people (71\%) did not use them. get the support of 15 respondents. So it can be concluded that there is a relationship between those who support the use of contraception and those who do not support more than those who support and those who do not support more than those who do not use it so that it is related to one another.
\end{abstract}

Keyword: Husband Support, IUD Contraception

\section{PENDAHULUAN}

Keluarga Berencana (KB) merupakan program dengan skala Nasional untuk menekan angka kelahiran.Program KB dirancang menciptakan kemajuan, kesejahtraan ekonomi, sosial serta spritual setiap penduduknya. Program Kb diawasi oleh BKKBN. Keluarga berencana adalah salah satu usaha untuk mencapai kesejahteraan dengan jalan memberikan nasihat perkawinan, pengobatan kemandulan dan penjarangan kehamilan. KB merupakan suatu "hak" semestinya harus berjalan tanpa paksaan dan disertai dengan informasi yang cukup kepada pasangan yang akan menjalani program KB (Irianto, 2014).

Di Afrika dari 23,6\% menjadi 27,6\%, di Asia telah meningkat dari 60,9\% menjadi 61,6\%, sedangkan Amerika latin dan Karibia naik sedikit dari 66,7\% menjadi 67,0\%. Diperkiraan 225 juta 
e-ISSN 2774-4671

Vol. 1 Nomor 2

Tahun 2021

Hal. $127-134$
JURNAL ILMIAH KEBIDANAN

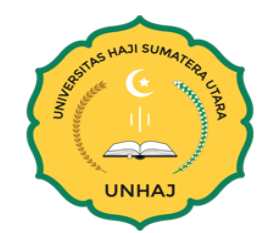

perempuan di negara-negara berkembang ingin menunda atau menghentikan kesuburan tapi tidak menggunakan metode kontrasepsi apapun dengan alasan sebagai berikut: terbatas pilihan metode kontrasepsi dan pengalaman efek samping. Kebutuhan yang belum terpenuhi untuk kontrasepsi masih terlalu tinggi. Ketidakadilan didorong oleh pertumbuhan populasi (WHO, 2014).

Sejalan dengan hasil Data Riset Kesehatan Dasar (RISKESDAS) menunjukkan bahwa pada tahun 2013 wanita usia 15-49 tahun dengan status kawin sebesar 59,3\% PUS menggunakan KB modern (Implan, MOW, MOP, IUD, Kondom, Suntik dan pil), dan 0,4\% menggunakan KB tradisional (MAL, Kalender dan Senggama terputus). Selain itu sebanyak 24,7\% PUS pernah melakukan KB dan 15,5 tidak melakukan KB. Jenis kontrasepsi yang sering banyak diminati oleh akseptor KB baru ialah suntik sebanyak 48,56\% (Kemeskes RI, 2014).

Kajian yang dilakukan oleh UNFPA 2012 banyak tantangan yang dihadapi pemerintah Kabupaten/ Kota dalam melaksanakan program KB, salah satunya tidak tersedia petugas lapangan KB. Berbagai upaya pemerintah dapat dilakukan untuk meningkatkan pemakaian alat kontrasepsi jangka panjang seperti IUD. Kontrasepsi IUD menjadi salah satu alat kontrasepsi yang dipikirkan pertama kali oleh wanita, karena dianggap cukup aman untuk sebagian besar wanita juga IUD bertahan lama. Penggunaan kontrasepsi IUD dari tahun ke tahun menunjukkan penurunan. Sementra efektifitas IUD untuk mengembalikan kesuburan tidak perlu diragukan.

Dukungan suami sebagai orang terdekat berperan penting bagi akseptor dalam pemilihan kontrasepsi. Keluarga sangat berperan penting dalam pemilihan alat kontrasepsi, karena jika ada salah satu keluarga yang tidak setuju, ibu akan mempertimbangkan ulang pilihannya misalnya ibu memilih IUD dan sebagian besar ibu akan ikut dengan keputusan suami, atau anggota keluarga yang lain. Perlu kerjasama semua pihak serta informasi yang tepat bagi calon akseptor apakah kontrasepsi yang dipilih sesuai tujuan.(Irianto, 2014).

Penggunaan IUD dipengaruhi oleh beberapa faktor, salah satu penelitian yang dilakukan di Sumatera Utara oleh Fatimah bahwa mayoritas responden penelitiannya berusia diatas $35(61,7 \%)$, berpendidikan SMA (61,7\%), mempunyai satu sampai dua orang anak $(51,1 \%)$, memiliki pengetahuan yang kurang tentang IUD (80,9\%), menyatakan bahwa efek samping merupakan salah satu faktor yang menyebabkan responden tidak menggunakan IUD $(59,6 \%)$, bersikap negatif terhadap IUD $(57,4 \%)$ dan tidak diberi dukungan oleh suami dan petugas KB untuk menggunakan $\operatorname{IUD}(72,3 \%)$.

Beberapa faktor yang mempengaruhi penggunaan kontrasepsi adalah dukungan suami dan pengalaman KB. Pengalaman istri dalam penggunaan kontrasepsi yang dipilih merupakan hal yang tidak terlupakan. Pengalaman baik akan selalu dijadikan acuan untuk mengikuti program keluarga berencana. Dukungan suami juga mempengaruhi penggunaan kontrasepsi, karena istri yang mendapat dukungan dari suami akan menggunakan kontrasepsi secara terus menerus sedangkan yang tidak mendapatkan dukungan akan sedikit yang menggunakan kontrasepsi (Aryanti, 2014).

Berdasarkan hasil penelitian di Lingkungan VIII Kelurahan Bandar Selamat Kecamatan Medan Tembung pada bulan November 2020 sampai Februari 2021 dengan 34 orang suami semua mengatakan mengetahui tentang kontrasepsi IUD, tetapi 24 orang suami tidak mendukung kontrasepsi IUD, 10 mendukung kontrasepsi IUD.

Berdasarkan latar belakang diatas maka peneliti melakukan penelitian yang berjudul "Dukungan Suami Terhadap Pemilihan Kontrasepsi IUD Di Lingkungan VIII Kelurahan Bandar Selamat Kecamatan Medan Tembung Tahun 2020. 


\section{METODE PENELITIAN}

Jenis penelitian ini dengan menggunkan metode survey analitikdengan pendekatan cross sectional, Rancangan penelitian yang digunakan adalah Deskriptif Analitik, karena hanya ingin mengetahui dukungan suami terhadap pemilihan kontrasepsi IUD di Lingkungan VIII Kelurahan Bandar Selamat Kecamatan Medan Tembung Tahun 2020. Pendekatan metode yang digunakan dengan pendekatan pendekatan cross sectional yaitu pengumpulan data sekaligus pada suatu saat, artinya subjek penelitian hanya observasi sekali saja dan pengukuran dilakukan terhadap variabel subjek pada saat pemeriksaan (point time approach).

Teknik pengambilan sampel secara accidental Sampling, yaitu sebagian atau secara kebetulan ada atau tersedia disuatu tempat sesuai konteks penelitian.

\section{HASIL DAN PEMBAHASAN}

Analisis data menggunakan analisa Unvariate dan analisa Bivariate. Analisis Univariate bertujuan untuk mennggambarkan karakteristik setiap variabel penelitian, sedangkan analisa Bivariate bertujuan untuk menujukan hubungan antara satu variabel bebas dan satu variabel terikat.

\subsubsection{Karakteristik Responden}

Berdasarkan penelitian yang dilakukan mengenai Dukungan Suami Terhadap Pemilihan Kontrasepsi IUD Di Lingkungan VIII Kelurahan Bandar Selamat Kecamatan Medan Tembung Tahun 2020 dari 34 orang responden didapatkan hasil distribusi responden yang diuraikan sebagai berikut :

Table 4.1 Distribusi Karakteristik Responden Berdasarkan Umur Di Lingkungan VIII Kelurahan Bandar Selamat Kecamatan Medan Tembung Tahun 2020.

\begin{tabular}{cccc}
\hline No & Umur & Jumlah & Presentasi (\%) \\
\hline 1 & $20-25$ & 9 & 26 \\
2 & $26-30$ & 13 & 38 \\
3 & $31-35$ & 12 & 36 \\
\hline & Total & $\mathbf{3 4}$ & $\mathbf{1 0 0} \%$ \\
\hline
\end{tabular}

Dari tabel 4.1 di atas menunjukan distribusi frekuensi responden berdasarkan umur mayoritas berumur 26-30 tahun sebanyak 13 orang (36\%) dan minoritas responden20-25 tahun sebanyak 9 orang $(26 \%)$.

Table 4.2 Distribusi Karakteristik Responden Berdasarkan Pendidikan Di Lingkungan VIII Kelurahan Bandar Selamat Kecamatan Medan Tembung Tahun 2020.

\begin{tabular}{cccc}
\hline No & Pendidikan & Jumlah & Presentasi (\%) \\
\hline 1 & SD & 11 & 32 \\
2 & SMP & 9 & 26 \\
3 & SMA & 8 & 21 \\
4 & Perguruan Tinggi & 6 & 21 \\
\hline & Total & $\mathbf{3 4}$ & $\mathbf{1 0 0 \%}$ \\
\hline
\end{tabular}


e-ISSN 2774-4671

Vol. 1 Nomor 2

Tahun 2021

Hal. $127-134$

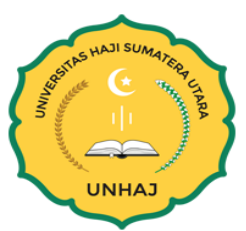

Dari tabel 4.2 di atas menunjukan distribusi frekuensi responden berdasarkan Pendidikan mayoritas berpendidikan SD sebanyak 11 orang (32\%) dan minoritas perguruan tinggi sebanyak 6 orang (17\%).

Table 4.3 Distribusi Karakteristik Responden Berdasarkan Pekerjaan Di Lingkungan VIII Kelurahan Bandar Selamat Kecamatan Medan Tembung Tahun 2020.

\begin{tabular}{cccc}
\hline No & Pekerjaan & Jumlah & Presentasi (\%) \\
\hline 1 & PNS & 7 & 21 \\
2 & Pedagang & 15 & 44 \\
3 & Wiraswasta & 12 & 35 \\
\hline & Total & $\mathbf{3 4}$ & $\mathbf{1 0 0}$ \\
\hline
\end{tabular}

Dari tabel 4.3 di atas menunjukan distribusi frekuensi responden berdasarkan pekerjaan adalah mayoritas bekerja sebagai pedagang sebanyak 15 orang (44\%) dan minoritas responden bekerja sebagai PNS sebanyak 7 orang (21\%).

Table 4.4 Distribusi Karakteristik Responden Berdasarkan Jenis Kontrasepsi Di Lingkungan VIII Kelurahan Bandar Selamat Kecamatan Medan Tembung Tahun 2020.

\begin{tabular}{cccc}
\hline No & Jenis Kontrasepsi & Jumlah & Presentasi (\%) \\
\hline 1 & IUD & 10 & 29 \\
2 & Tidak IUD & 24 & 71 \\
\hline & Total & $\mathbf{3 4}$ & $\mathbf{1 0 0}$ \\
\hline
\end{tabular}

Dari tabel 4.4 di atas menunjukan distribusi frekuensi responden berdasarkan jenis kontrasepsi adalah mayoritas jenis kontrasepsi tidak IUD sebanyak 24 orang (71\%) dan minoritas responden jenis kontrasepsi IUD sebanyak 10 orang (29\%).

Table 4.5 Distribusi Karakteristik Responden Berdasarkan Paritas Di Lingkungan VIII Kelurahan Bandar Selamat Kecamatan Medan Tembung Tahun 2020.

\begin{tabular}{cccc}
\hline No & Paritas & Jumlah & Presentasi (\%) \\
\hline 1 & Primigravida & 3 & 9 \\
2 & Skundigravida & 9 & 26 \\
3 & Multipara & 20 & 59 \\
4 & Grande Multigravida & 2 & 6 \\
\hline & Total & $\mathbf{3 4}$ & $\mathbf{1 0 0}$ \\
\hline
\end{tabular}

Dari tabel 4.5 di atas menunjukan distribusi frekuensi responden berdasarkan paritas mayoritas multigravida sebanyak 20 orang (59\%) dan minoritas responden primigravida sebanyak 3 orang $(9 \%)$.

Table 4.6 Distribusi frekuensi Dukungan Suami Terhadap Jenis Kontrasepsi Intra Uterine Device (IUD) Di Lingkungan VIII Kelurahan Bandar Selamat Kecamatan Medan Tembung Tahun 2020.

\begin{tabular}{cccc}
\hline No & Dukungan Suami & Jumlah & Presentasi (\%) \\
\hline 1 & Mendukung & 15 & 44 \\
2 & Tidak Mendukung & 19 & 56 \\
\hline & Jumlah & $\mathbf{3 4}$ & $\mathbf{1 0 0}$
\end{tabular}




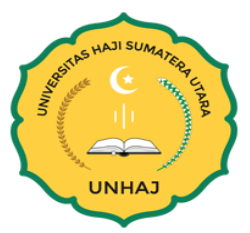

Dari tabel 4.6 di atas menunjukan distribusi frekuensi responden tentang IUD mayoritas tidak mendukung sebanyak 19 orang (56\%) dan minoritas mendukung sebanyak 15 orang (44\%).

\subsection{Analisis Bivariat Hasil Uji Chi Square Correlation}

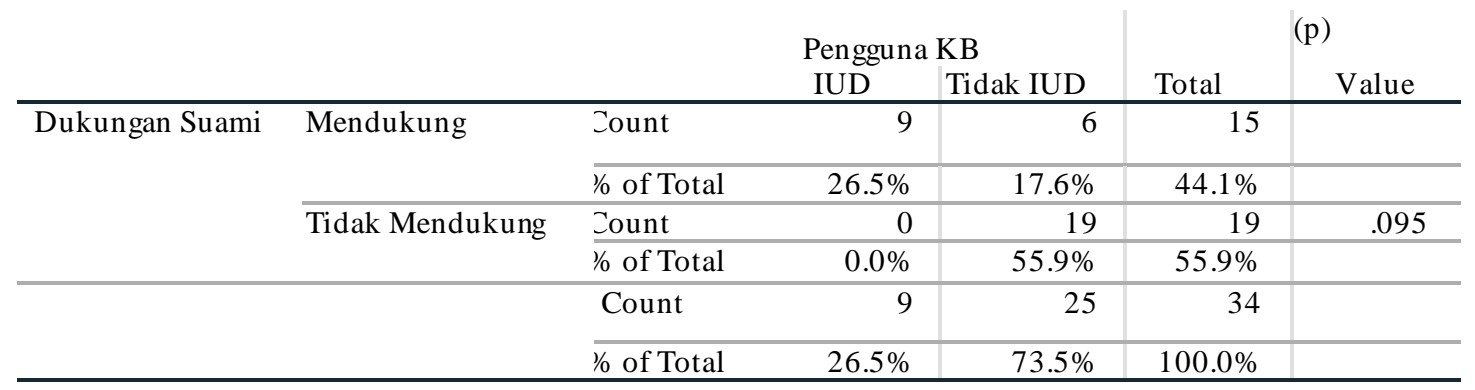

Dari tabel 4.12 dapat dilihat bahwa yang tidak mendapatkan dukungan suami sebanyak 19 responden ( 55,9\%) yang menggunakan kontrasepsi IUD ada 15 orang $(44,1 \%)$ dan yang tidak menggunakan kontrasepsi IUD ada 19 orang ( 55,9\%) sedangkan yang mendapat dukungan sebanyak 15 orang $(44,1 \%)$ yang menggunakan ada 15 orang $(44,1 \%)$. Berdasarkan uji statistic diperoleh nilai $\mathrm{p}$ (value) $=.095$. Berdasarkan hasil tersebut menunjukan bahwa ada hubungan yang signifikan antara dukungan suami dengan pemilihan kontrasepsi IUD. Artinya dukungan suami mempengaruhi kontrasepsi IUD di Lingkungan VIII Kelurahan Bandar Selamat Kecamatan Medan Tembung Tahun 2020.

Berdasarkan hasil uji chi-squer, di peroleh nilai p (value) $=.095$ yang berarti bahwa secara statistik menunjukan adanya hubungan yang bermakna antara dukungan suami dalam penggunaan kontrasepsi IUD di Lingkungan VIII Kelurahan Bandar Selamat Kecamatan Medan Tembung Tahun 2020.

Dukungan suami sangatlah berdampak positif bagi keluarga terlebih dengan pasangannya, karena adanya dukungan suami terutama dalam pemilihan IUD, maka istri akan merasa percaya diri dalam memilih dan selama pemakaiannya istri tidak akan khawatir karena telah mendapat dukungan oleh suami.

Hal ini menunjukkan bahwa terori dan hasil penelitian hampir memiliki kesamaan, dukungan suami merupakan salah satu faktor utama yang mempengaruhi pemilihan kontrasepsi. Bagi ibu, dukungan suami terhadap ibu sikap yang harus dikembangkan karena pada hakikatnya dukungan suami sangatlah berdampak positif bagi sang istri. 


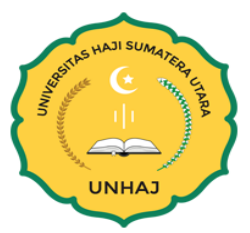

\section{KESIMPULAN}

Berdasarkan hasil penelitian didapat beberapa kesimpulan antara lain :

1. Umur

Dukungan Suami terhadap Pemilihan Kontrasepsi IUD Di Lingkungab VIII Kelurahan Bandar Selamat Kecamatan Medan Tembung berdasarkan umur mayoritas berumur 26-30 tahun sebanyak 13 orang $(36 \%)$ dan minoritas responden 20-25 tahun sebanyak 9 orang $(26 \%)$.

2. Pendidikan

Dukungan Suami terhadap Pemilihan Kontrasepsi IUD Di Lingkungab VIII Kelurahan Bandar Selamat Kecamatan Medan Tembung berdasarkan Pendidikan mayoritas berpendidikan SD sebanyak 11 orang (32\%) dan minoritas perguruan tinggi sebanyak 6 orang (17\%).

3. Pekerjaan

Dukungan Suami terhadap Pemilihan Kontrasepsi IUD Di Lingkungab VIII Kelurahan Bandar Selamat Kecamatan Medan Tembung berdasarkan berdasarkan pekerjaan adalah mayoritas bekerja sebagai pedagang sebanyak 15 orang (44\%) dan minoritas responden bekerja sebagai PNS sebanyak 7 orang (21\%).

4. Jenis Kontrasepsi

Dukungan Suami terhadap Pemilihan Kontrasepsi IUD Di Lingkungan VIII Kelurahan Bandar Selamat Kecamatan Medan Tembung berdasarkan jenis kontrasepsi adalah mayoritas jenis kontrasepsi tidak IUD sebanyak 24 orang (71\%) dan minoritas responden jenis kontrasepsi IUD sebanyak 10 orang $(29 \%)$.

5. Paritas

Dukungan Suami terhadap Pemilihan Kontrasepsi IUD Di Lingkungan VIII Kelurahan Bandar Selamat Kecamatan Medan Tembung berdasarkan paritas mayoritas multigravida sebanyak 20 orang $(59 \%)$ dan minoritas responden primigravida sebanyak 3 orang $(9 \%)$.

6. Dukungan Suami

Dukungan Suami terhadap Pemilihan Kontrasepsi IUD Di Lingkungan VIII Kelurahan Bandar Selamat Kecamatan Medan Tembung berdasarkan dari tabel 4.6 di atas menunjukan distribusi frekuensi responden tentang IUD mayoritas tidak mendukung sebanyak 19 orang (56\%) dan minoritas mendukung sebanyak 15 orang (44\%).

\section{SARAN}

Saran yang dikemukakan berdasarkan kesimpulan penelitian diatas sebagai berikut:

1. Bagi Responden

Diharapkan dapat dijadikan sumber informasi dan bahan masukan. Bagi keluarga tentang kontrasepsi IUD di Lingkungan VIII Kelurahan Bandar Selamat Kecamatan Medan Tembung.

2. Bagi Peneliti

Diharapkan peneliti bisa menerapkan kepada masyarakat dan bisa memperbaiki pelaksanaan kontrasepsi di masyarakat.

3. Bagi Institusi Pendidikan 
e-ISSN 2774-4671

Vol. 1 Nomor 2

Tahun 2021

Hal. $127-134$

\section{JURNAL ILMIAH KEBIDANAN}

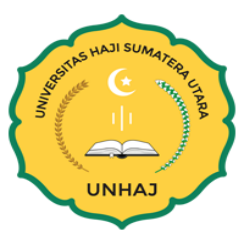

Diharapkan hasil penelitian ini dapat menjadi direferensi dan bahan bacaan di perpustakaan dan sumber informasi untuk melakukan penyuluhan kesehatan di masyarakat.

\section{DAFTAR PUSTAKA}

Anggraini, Yetti. Marini. 2017. Pelayanan Keluarga Berencana, Yogyakarta, Rohima Press.

Atiyah, Yetti. Zulfendi. Evarina. 2017. Hubungan Sosial Budaya, Persepsi, Ketakutan Akan Pemasangan dengan Pilihan Ibu Dalam Menggunakan Kontrasepsi AKDR di Desa Telaga Sari Kecamatan Tanjung Morawa Kabupaten Deli Serdang.

BKKBN, Kemenkes RI. 2011. Buku Panduan Praktis Pelayanan Kontrasepsi, Jakarta, Tridasa Printer.

Handayani, Sri. 2016. Buku Ajar Pelayanan Keluarga Berencana, Yogyakarta, Pustaka Rihama

Hidayat, Aziz Alimul. 2011. Metode Penelitian Kebidanan dan Teknik Analisa Data. Jakarta, Salemba Medika.

Mariati, Titik. 2018. Dukungan Suami dengan Pemilihan Penggunaan Kontrasepsi Intra Uterine Device (IUD) Jurnal Manajemen Kesehatan Yayasan Rs. Dr. Soetomo. 4(2) : 98-109).

Notoadmojo, Soekijo. 2010. Metodologi Penelitian Kesehatan. Jakarta, Rineka Cipta.

Proverawati, Atikah, Anisa Dwi Islaely. 2016. Panduan Memilih Kontrasepsi, Yogyakarta, Nuha Medika.

Retnowati, Yuni. Doris Novianti. Kiku Wulandari, 2018. Dukungan Suami Terhadap Pemilihan Kontrasepsi Intrauterin Device di Wilayah Kerja Puskesmas Mamburungan, Journal of Borneo Holistic Health, 1(1) : 73-84.

Siti, Mulyani Nina, Mega Rinawati. 2013. Keluarga Becana dan Alat Kontrasepsi, Yogyakarta, Nuha Medika.

Sugiono, 2017. Metode Penelitian Kuantitatif, Kualitatif, Bandung, Alfabeta.

Wawan, A. Dewi M. 2019, Teori \& Pengukur Pengetahuan, Sikap \& Perilaku Manusia, Yogyakarta, Nuha Media.

Yuhedi, Lucky Taufika, Titik Kurniawati. 2018. Buku Ajar Kependudukan dan Pelayanan KB, Jakarta, EGC.

http://scholar.unand.ac.id/38427/2/babIpendahuluan. Diakses tanggal 19 Oktober 2019. 

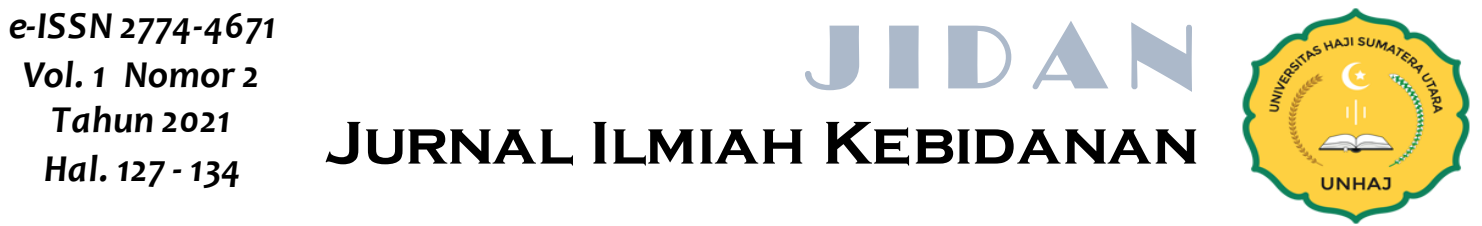

http://eprints.ums.ac.id/37661/4/bab\%201.pdf. Diakses tanggal 19 Oktober 2019.

http://eprints.ums.ac.id/37998/5/01.bab1\%201.pdf. Diakses tanggal 19 Oktober 2019.

www.jurnal.stikes-yrsds.ac.id. Diakses tanggal 19 Oktober 2019. 